\title{
Mitigation of Greenhouse Gas Emissions from Tropical Soils Amended with Poultry Manure and Sugar Cane Straw Biochars
}

\author{
Sarah Vieira Novais ${ }^{*}$, Mariana Delgado Oliveira Zenero ${ }^{1}$, Elizio Ferreira Frade Junior ${ }^{1}$, \\ Renato Paiva de Lima ${ }^{2}$, Carlos Eduardo Pelegrino Cerri ${ }^{1}$ \\ ${ }^{1}$ Department of Soil Science, Escola Superior de Agricultura Luiz de Queiroz, University of São Paulo, Piracicaba, Brazil \\ ${ }^{2}$ Department of Environmental Sciences, Federal Institute of Mato Grosso, Barra do Garça, Brazil \\ Email: *sarahnovais@usp.br, marianadelgado@usp.br, eliziojr@yahoo.com.br, renato.lima@bag.ifmt.edu.br, cepcerri@usp.br
}

How to cite this paper: Novais, S.V., Zenero, M.D.O., Frade Junior, E.F., de Lima, R.P. and Cerri, C.E.P. (2017) Mitigation of Greenhouse Gas Emissions from Tropical Soils Amended with Poultry Manure and Sugar Cane Straw Biochars. Agricultural Sciences, 8, 887-903.

https://doi.org/10.4236/as.2017.89065

Received: May 15, 2017

Accepted: August 31, 2017

Published: September 5, 2017

Copyright $\odot 2017$ by authors and Scientific Research Publishing Inc. This work is licensed under the Creative Commons Attribution International License (CC BY 4.0).

http://creativecommons.org/licenses/by/4.0/

\begin{abstract}
Increases in greenhouse gases (GHG) emissions, upon changes in land use and agricultural management, lead to a search for techniques that enhance carbon residence time in soil. Pyrolysis increases the recalcitrance of organic materials and enhances their activities as physical, chemical and biological soil conditioners. Emissions of $\mathrm{CO}_{2}, \mathrm{CH}_{4}$ and $\mathrm{N}_{2} \mathrm{O}$ quantified from a sandy soil

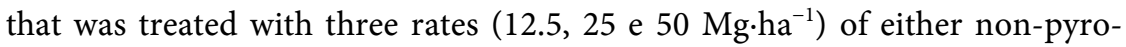
lysed poultry manure and sugarcane straw or biochars, pyrolysed at two contrasting temperatures $\left(350^{\circ} \mathrm{C}\right.$ and $\left.650^{\circ} \mathrm{C}\right)$. Subsequently, the flux of the three gases was converted and compared in a standard unit $\left(\mathrm{CO}_{2} \mathrm{eq}\right)$. The added biochars, significantly reduced GHG emissions, especially $\mathrm{CO}_{2}$, relative to the non-pyrolysed materials. The greatest differences between applied rates of poultry manure, relative sugarcane straw, both to biochar and raw material, and the positive response to the increase of pyrolysis temperture, confirm the importance of raw material choice for biochar production, with recalcitrance being an important initial characteristic. Greater emissions occurred with intermediate rate of biochars $\left(25 \mathrm{Mg} \cdot \mathrm{ha}^{-1}\right)$ amendment to the soil. These intermediate rates had higher microbial biomass, provided by an intermediate $\mathrm{C} / \mathrm{N}$ ratio derived from the original soil and the biochar, promoting combined levels of labile $\mathrm{C}$ and oxygen availability, leading to an optimal environment for microbiota.
\end{abstract}

\section{Keywords}

$\mathrm{CO}_{2}, \mathrm{CH}_{4}, \mathrm{~N}_{2} \mathrm{O}$, Weathered Soil 


\section{Introduction}

The predicted increase in greenhouse gas emissions (GHG) and the growing demand for manufactured goods [1] promote the adoption of soil management techniques that mitigate these emissions [2] and [3]. Soils can sequester and accumulate larger quantities of carbon than plant biomass and the atmosphere [4]. For the global carbon cycle, any activity that favors the decomposition and mineralization of organic material, with consequent carbon emission, should be avoided [1].

Numerous studies have investigated carbon residence time in soil, as in charcoal form ("biochar") [5] and [6]. Biochar is the product obtained from pyrolysis of various biomasses. This process occurs in the absence of oxygen (anoxic environment) or at a very low level (hypoxic environment), which produces condensable gases and vapor, as well as charcoal [7]. The pyrolysis temperature alters the proportion of fulvic and humic acids in biochar [5], concentration of nutrients, such as phosphorous and nitrogen [8], $\mathrm{pH}$ and porosity [9]. Aromatic and hydrophobic structures give stability, enhancing recalcitrance, and acidic groups give reactivity [4], making biochar useful to increase chemical, physical and biological qualities of soils. In regard of plant biomass, hemicellulose is the first to be lost in the pyrolysis process, since it degrades at $200^{\circ} \mathrm{C}$. From $240^{\circ} \mathrm{C}$ to $350^{\circ} \mathrm{C}$, cellulose is degraded, followed by lignin at $280^{\circ} \mathrm{C}$ a $500^{\circ} \mathrm{C}$ [10].

There is a wide choice of raw materials that generate environmental problems upon their accumulation in the fields [11] and [12]. According to [13], agricultural soils, enteric fermentation and animal waste, are responsible for $70 \%$ of GHG emissions in AFOLU areas (Agriculture, Forestry and Other Land Use), making necessary an appropriate management of these materials. For instance, sugar cane, planted on 8.8 million hectares in Brazil, which generates, approximately, 250 million tons of straw [14], had recent laws prohibiting straw burning, which limits the management options for this residue [15]. The straw left in the field retards sprouting and tillering, reduces productivity [16], and also affects the growth and development of sockets [16]. Since two thirds of biomass produced by sugarcane is considered bagasse and straw [17], biochar production is an alternative for the management of this waste [18]. Furthermore, animal residues also have a large contribution in GHG emissions [19], and are difficult in transport and store. Increased poultry production and concerns about the waste, poses the need for an environmentally secure deposit for this residue [20].

Since biochar has higher carbon stability than the original raw material, it is relevant to GHG mitigation [6] [10] [11] and [12]. [21] concluded that pyrolysis of wheat straw would avoid the emission of 0.9 to $1.06 \mathrm{t} \mathrm{CO}_{2}$ eq per ton of dry weight, if the non-pyrolysed straw was allowed to decompose in the field. [22] predicted that the use of biochar could sequester 3.7 to $6.6 \mathrm{Pg} \mathrm{CO}_{2}$ eq by 2050 , contributing 7 to $13 \%$ reduction in GHG emissions. [23] calculated a reduction of 0.7 to $1.3 \mathrm{t} \mathrm{CO}_{2}$ eq per ton of miscanthus, when the waste is used on biochar 
production. [24] compared biochar from corn and grass straw in the USA and demonstrated a reduction of $0.885 \mathrm{t} \mathrm{CO}_{2}$ eq per ton of dry weight in GHG emissions. [12] considered the energy used in pyrolysis and calculated that the incorporation of biochar into the soil would reduce emissions by 2.8 to $10.2 \mathrm{Mt}$ $\mathrm{CO}_{2}$ eq by 2030 and 2.9 to $10.6 \mathrm{Mt} \mathrm{CO}_{2}$ eq by 2050 . The variation in emissions between these values is influence by the type of raw material used to produce the biochars. This author [12] observed that the highest potential for GHG emission reduction occurred with forestry residues, followed by straw from cereals and pastures; the lowest potential was biochars derived from cattle manure. [25] measured $\mathrm{CO}_{2}$ and $\mathrm{CH}_{4}$ emissions and did not obtain a significant difference between the untreated soil and soil amended with biochar from wheat straw; however, a significant difference in $\mathrm{N}_{2} \mathrm{O}$ emission was observed. [26] observed an increase in $\mathrm{CH}_{4}$ emissions of $200 \mathrm{mg} \cdot \mathrm{m}^{-2}$ when applying $20 \mathrm{Mg} \cdot \mathrm{ha}^{-1}$ of biochar from forestry residues on an unfertile tropical soil. However, [27] observed a reduction of $51.1 \%$ in $\mathrm{CH}_{4}$ emission from a waterlogged paddy soil when applied biochar from bamboo fragments and, a reduction of 91.2\%, when biochar from rice husks was applied, likely due to a reduction in methanogenic.

Under tropical soil conditions, there are a limited number of published results on biochar and its impacts on GHG emissions. Few investigations in Brazil compare different materials and rates of applied biochar. Therefore, the objective of this study was to quantify and compare GHG emissions from a tropical sandy soil, which received either different amounts of biochars from sugar cane straw and poultry manure, pyrolysed in two temperatures, or their respective non-pyrolysed materials.

\section{Material and Methods}

\subsection{Soil Characteristics}

About $30 \%$ of the Brazilian territory is occupied by sandy soils [28]. With proper management and fertilization, these soils are intensively cultivated and are highly productive [29]. Samples from the $0-20 \mathrm{~cm}$ layer of a Typic Quartzipsamment soil type (Table 1) were collected from the Anhembi region of São Paulo State $\left(22^{\circ} 43^{\prime} 31.1^{\prime \prime S}\right.$ e $\left.48^{\circ} 01^{\prime} 20.2^{\prime \prime} \mathrm{W}\right)$ under natural vegetation. The samples were dried, sieved to $2 \mathrm{~mm}$ size and $50 \mathrm{~g}$ of soil were incubated with the raw materials and the respective biochars, in different treatments.

Table 1. Characteristics of the tropical sandy soil used in the experiment.

\begin{tabular}{cccccc}
\hline \multirow{2}{*}{ Soil } & Sand/Silt/Clay & $\mathrm{pH}$ & $\mathrm{C}$ & $\mathrm{N}$ & $\mathrm{C} / \mathrm{N}$ \\
\cline { 2 - 6 } & $\mathrm{g} \cdot \mathrm{kg}^{-1}$ & $\mathrm{CaCl}_{2}$ & & $\%$ & \\
\hline Typic Quartzipsamment & $900 / 22 / 78$ & $4.1 \pm 0.1$ & $0.9 \pm 0.1$ & $0.1 \pm 0.0$ & $14.3 \pm 0.1$ \\
\hline
\end{tabular}

Source: Abruzzini, 2015 [52]. 


\subsection{Raw Materials Selection}

The raw materials were selected due to their abundant accumulation in the field, plus their contrasting attributes and characteristics of agronomic interests. Sugar cane straw was collected from a field of cane industry at Piracicaba-SP, and poultry manure was collected from a farm located at ESALQ-USP. The raw materials were dried at $45^{\circ} \mathrm{C}$, ground in a ball mill and sieved to $2 \mathrm{~mm}$, forming a homogeneous material.

\subsection{Biochar Production}

Pyrolysis process was carried out by SPPT Company, in metallic reactors, with an $\mathrm{N}_{2}$-saturated atmosphere. The temperature was raised by $10^{\circ} \mathrm{C}$ per minute during the first $30 \mathrm{~min}$ followed by $20^{\circ} \mathrm{C}$ per min up to the desired temperatures [30].

Two pyrolysis temperatures, $350^{\circ} \mathrm{C}$ and $650^{\circ} \mathrm{C}$, were chosen based on values cited in the literature. These temperatures cover the main phases of transformation of raw materials, that results in the final characteristics of the produced biochar. Temperatures below $350^{\circ} \mathrm{C}$ are considered toast rather than pyrolysis, while above $650^{\circ} \mathrm{C}$ results in weight loss of the material [31].

[30] previously characterized these biochars according to their $\mathrm{pH}$, electrical conductivity (EC), cation exchange capacity (CEC), elemental analysis, humidity, relative proportions, yield and biochemical composition (Table 2), as well as spectrometric analysis.

Table 2. Properties of the biochars from poultry manure (PM) and sugar cane straw (CS) pyrolyzed at $350^{\circ} \mathrm{C}$ and $650^{\circ} \mathrm{C}$.

\begin{tabular}{|c|c|c|c|c|}
\hline \multirow[b]{2}{*}{ Properties } & \multicolumn{4}{|c|}{ Biochar } \\
\hline & $\mathrm{PM} 350^{\circ} \mathrm{C}$ & $\mathrm{PM} 650^{\circ} \mathrm{C}$ & $\operatorname{CS} 350^{\circ} \mathrm{C}$ & $\operatorname{CS} 650^{\circ} \mathrm{C}$ \\
\hline $\mathrm{pH}\left(\mathrm{CaCl}_{2}\right)$ & 8.3 & 10.0 & 8.8 & 9.2 \\
\hline $\mathrm{EC}\left(\mu \mathrm{S} \cdot \mathrm{cm}^{-1}\right)$ & 4256.3 & 4022.5 & 1788.7 & 1911.4 \\
\hline $\mathrm{CEC}\left(\mathrm{mmol}_{\mathrm{c}} \cdot \mathrm{kg}^{-1}\right)$ & 360.0 & 200.0 & 70.0 & 70.0 \\
\hline C (\%) & 60.8 & 68.2 & 36.3 & 32.6 \\
\hline $\mathrm{N}(\%)$ & 1.8 & 1.7 & 2.6 & 1.4 \\
\hline $\mathrm{O}(\%)$ & 37.5 & 26.8 & 53.4 & 62.3 \\
\hline $\mathrm{H}(\%)$ & 2.5 & 2.7 & 3.3 & 0.8 \\
\hline Moisture (\%) & 3.8 & 4.2 & 2.9 & 1.7 \\
\hline Volatile Material (\%) & 50.2 & 43.8 & 60.8 & 42.1 \\
\hline Ash (\%) & 24.2 & 13.9 & 32.2 & 48.8 \\
\hline C fixed (\%) & 21.9 & 36.7 & 0.0 & 7.5 \\
\hline Biochar yield (\%) & 41.5 & 32.8 & 59.6 & 40.2 \\
\hline Hemicellulose $\left(\mathrm{g} \cdot \mathrm{kg}^{-1}\right)$ & 53.2 & 78.8 & 211.5 & 291.0 \\
\hline Cellulose $\left(\mathrm{g} \cdot \mathrm{kg}^{-1}\right)$ & 56.9 & 72.3 & 82.3 & 75.3 \\
\hline Lignin $\left(\mathrm{g} \cdot \mathrm{kg}^{-1}\right)$ & 734.9 & 598.4 & 295.4 & 233.7 \\
\hline
\end{tabular}

Source: Conz, 2015. 


\subsection{Treatments and Experimental Conditions}

Each biochar and their respective raw material were homogenized with the soil at $60 \%$ field water holding capacity. This soil moisture content approximated the filling of the micro-pores [32], guarantying microorganisms preservation. Each soil treatment mixture was placed in $650 \mathrm{~mL}$ glass pots, with a septum in the top, allowing gas collection with a syringe after sealing. A small vial containing deionized water was positioned in the glass pots to maintain humidity and the water was replenished upon observation of weight loss in the experimental unit.

The experiment consisted in a factorial treatment combination $[3 \times(2+(2 \times$ $2))]+1$, with three rates $\left(12.5 ; 25\right.$ and $\left.50 \mathrm{Mg} \cdot \mathrm{ha}^{-1}\right)$ of applied biochar or nonpyrolysed material, two raw materials (sugar cane straw and poultry manure), two biochars (from sugar cane straw and from poultry manure), and two pyrolysis temperatures $\left(350^{\circ} \mathrm{C}\right.$ and $\left.650^{\circ} \mathrm{C}\right)$, totaling 18 treatments, with four replicates and a control with untreated soil.

The application rates, defined according to [22], correspond to the maximum viable amount of applied biochar, considered by these authors as $50 \mathrm{Mg} \cdot \mathrm{ha}^{-1}$. The other two rates $\left(12.5\right.$ and $25 \mathrm{Mg} \cdot \mathrm{ha}^{-1}$ ) are fractions of this value.

The experimental units were maintained for 6 months in the Soil Organic Matter Laboratory, in Soil Science Department at ESALQ/USP, at a constant temperature of $25^{\circ} \mathrm{C}$. Starting time was when the biochar was incorporated into the soil and incubated in the glass pots.

\subsection{Gas Sampling}

Gas emissions, collected daily during the first two weeks and less frequently during the rest of the experimental period, were sampled after sealing the vials for 30 minutes, using a $25 \mathrm{~mL}$ syringe and needle. Five empty flasks, used as control samples, were the background established levels used to calculate the effective concentration of the gasses emitted from each treatment (Equation 1). The gas samples were immediately transferred to vials under vacuum and analyzed by gas-chromatography (SRI 8610-SRI Instruments) with a flame ionization detector (FID) and an electron capture detector ${ }^{63} \mathrm{Ni}$ (ECD), which permitted the detection of $\mathrm{CO}_{2}, \mathrm{CH}_{4}$ and $\mathrm{N}_{2} \mathrm{O}$ in the same sample.

$$
\mathrm{NET}=\mathrm{AET}-\mathrm{BEC}
$$

where: NET is the net emission of GHG for the treatment; AET is the accumulated emission of GHG for the treatment; BEC is the background emissions in the control sample.

\subsection{Post-Experiment Analysis}

After the end of the experiment, carbon (C) and nitrogen (N) contents from each experimental unit were analyzed by dry combustion using a Leco TruSpec ${ }^{\oplus}$ CHN elemental analyzer, according to [33] Microbial biomass C and N (MBC and $\mathrm{MBN}$ ) were determined by the fumigation-extraction method proposed by 
[34]. The extracts from each experimental unit were analyzed using a Shimadzu Total Organic Carbon Analyzer (TOC-L) and a Total Organic Nitrogen Analyzer (TON-L).

\subsection{Data Analysis and Statistics}

Mean gas concentrations were used to calculate flow and accumulation and were subjected to an adjustment by a second order polynomial equation (gas concentration versus time), as proposed by [35]. The flows at zero time (empty vials) were calculated by the second order derivative equations and expressed per gram of $\mathrm{C}$ or $\mathrm{N}$ per unit area $\left(\mathrm{m}^{2}\right)$ or per unit time $(\mathrm{h})$.

The conversion of the flux of the three gases into a standard unit $\left(\mathrm{CO}_{2}\right.$ equivalent), allowing a critical and ensemble view of GHG emissions, was obtained according to Equations (2) and (3).

$$
\begin{aligned}
& \mathrm{CO}_{2 \mathrm{eq}}=\mathrm{C}-\mathrm{CH}_{4} \times \frac{16}{12} \times 25 \\
& \mathrm{CO}_{2 \mathrm{eq}}=\mathrm{N}-\mathrm{N}_{2} \mathrm{O} \times \frac{44}{28} \times 298
\end{aligned}
$$

where: $\mathrm{C}-\mathrm{CH}_{4}$ and $\mathrm{N}-\mathrm{N}_{2} \mathrm{O}$ are gases fluxes $\left(\mathrm{mg} \cdot \mathrm{m}^{-2} \cdot \mathrm{h}^{-1}\right) ; 16 / 12$ is the ratio between the molecular mass of $\mathrm{CH}_{4}$ and $\mathrm{C} ; 44 / 28$ is the rate between the molecular mass of $\mathrm{N}_{2} \mathrm{O}$ and N; 25 is the Global Warming Potential (GWP) of $\mathrm{CH}_{4}$ and 298 of $\mathrm{N}_{2} \mathrm{O}$ [36].

The data from the raw materials, combined by application rate and feedstock, were subjected to a variance analysis, where a completely randomized design was adopted, in a factorial $2 \times 3$, with a control treatment and four replicates. To analyze the data from the biochars, the same experimental design was adopted, in a factorial $2 \times 3 \times 2$. The factors were combined with the raw material used in pyrolysis process, application rates and temperatures, four replicates and the control. The means, treated as separate events, were compared between treatments at a confidence interval of $95 \%$. The treatments were considered not to be statistically different among themselves when there was an overlap of the mean intervals. Results on $\mathrm{MBC}, \mathrm{MBN}, \mathrm{C}$ and $\mathrm{N}$ contents and $\mathrm{C} / \mathrm{N}$ ratio were statistically analyzed using a Tukey test at $5 \%$. The statistical analyses and graphs were performed using the "plotrix" and "agricolae" packages available in the R software [37].

\section{Results}

\subsection{Raw Materials}

Poultry manure (PM) provided the largest $\mathrm{CO}_{2}$ (Figure $1(\mathrm{a})$ ) emissions and the largest amplitude between the applied rates (Figure 1(a)). The greater emissions of $\mathrm{CO}_{2}$ by the raw materials, relative to their respective biochars (Figure 1(a) and Figure 1(b)), can be observed by the magnitude of the y-axis, which are three times larger for the raw materials. Even though there was little or no statis- 


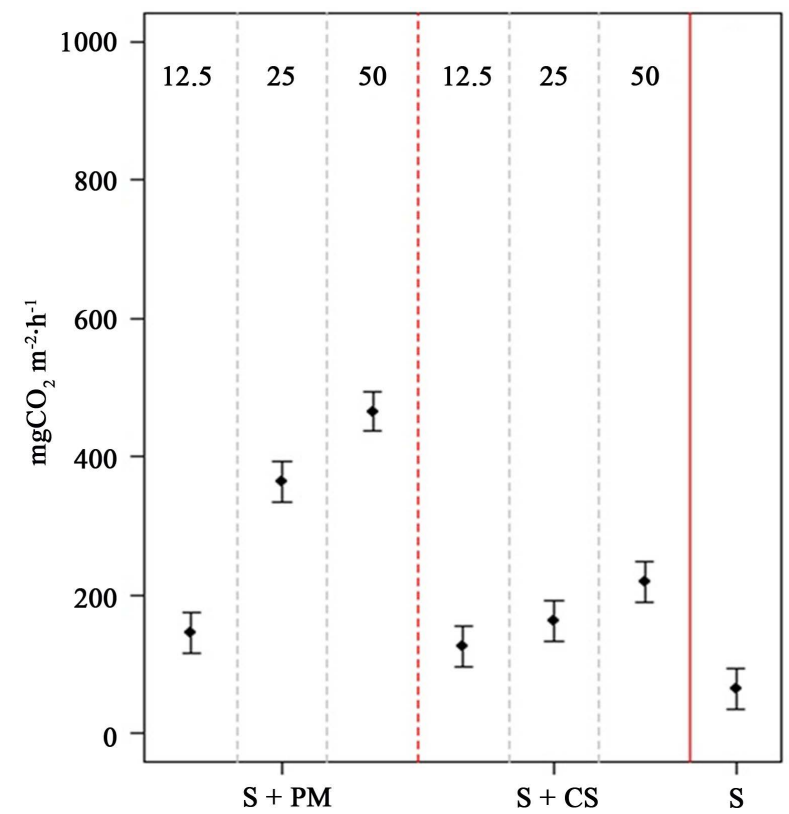

(a)

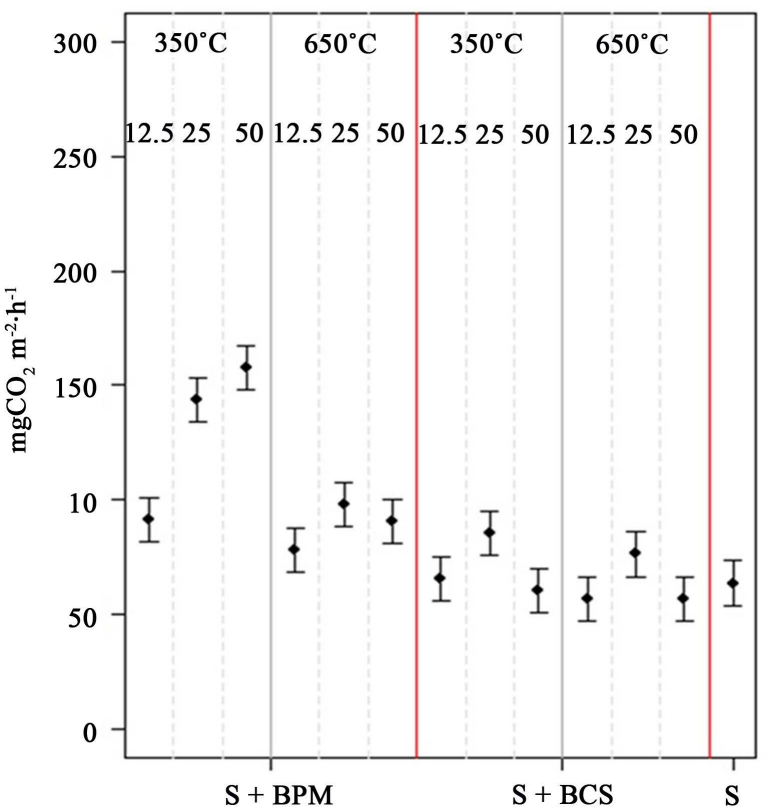

(b)

Figure 1. Emission of $\mathrm{CO}_{2}$ from a tropical sandy soil (S) amended with (a) raw materials: poultry manure (S + PM) and sugar cane straw $(S+C S)$; and (b) biochars: biochar poultry manure $(S+B P M)$ and biochar of sugar cane straw $(S+B C S)$.

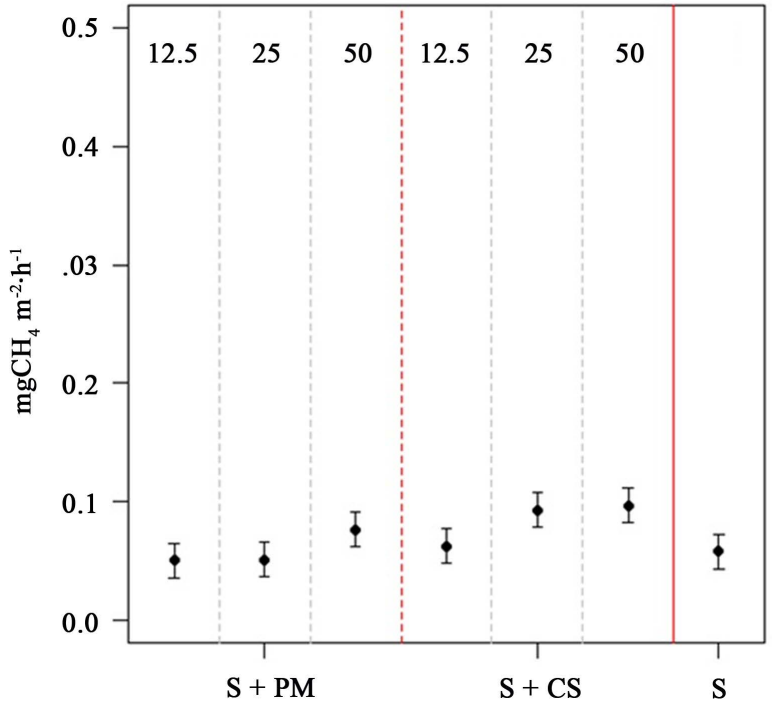

(a)

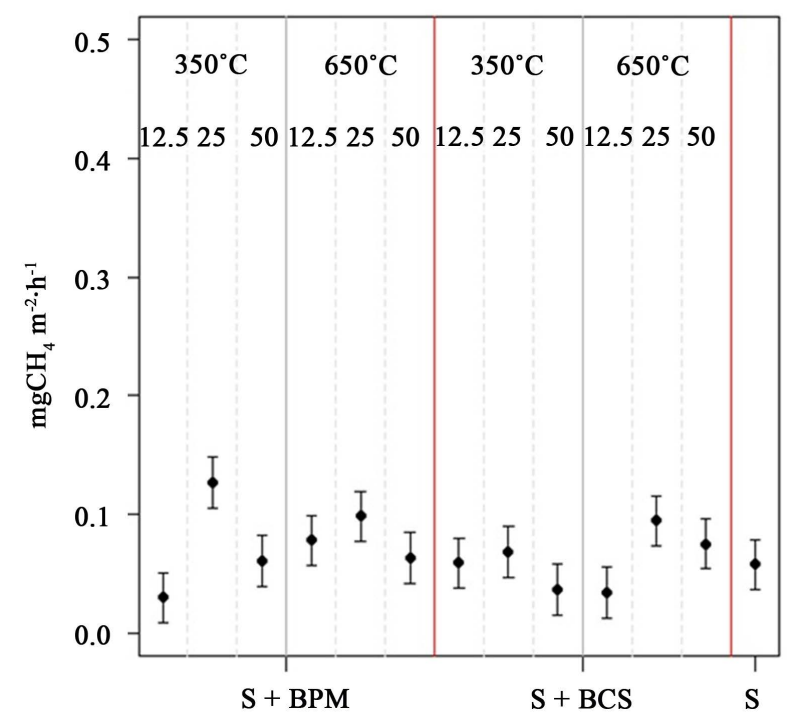

(b)

Figure 2. Emission of $\mathrm{CH}_{4}$ from a tropical sandy soil (S) amended with a) raw materials: poultry manure (S + PM) and sugar cane straw $(S+C S)$; and b) biochars: biochar poultry manure $(S+B P M)$ and biochar of sugar cane straw $(S+B C S)$.

tical difference in $\mathrm{CH}_{4}$ emissions among rates and raw materials, the pattern of higher emission occurred for the highest application rate (Figure 2(a)).

\subsection{Biochars}

When the emissions of $\mathrm{CO}_{2}$ from the biochars were compared (Figure 1(b)), the same trends between raw materials were observed. Even after pyrolysis, PM 


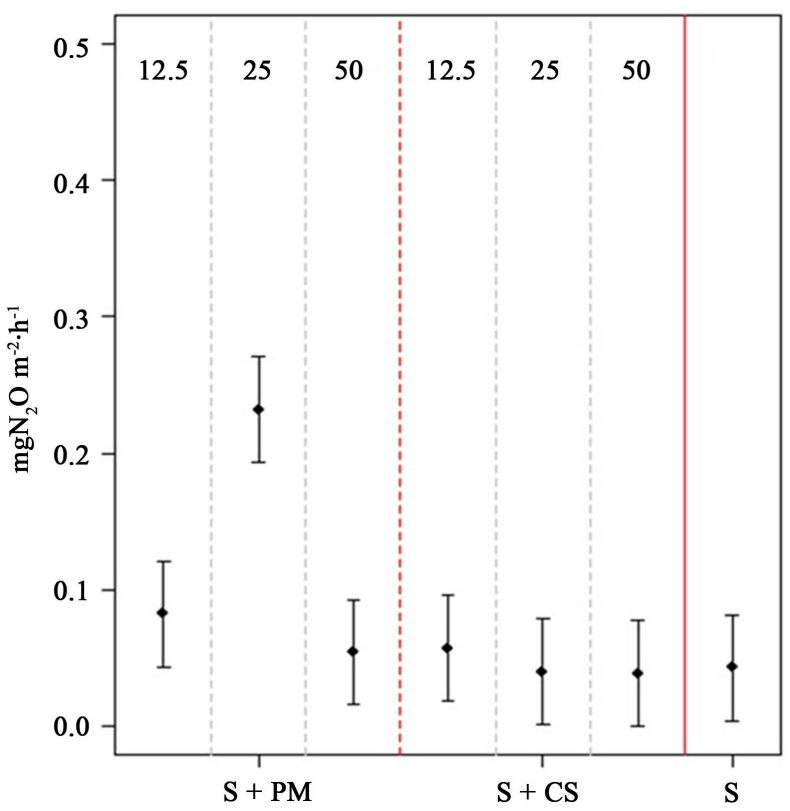

(a)

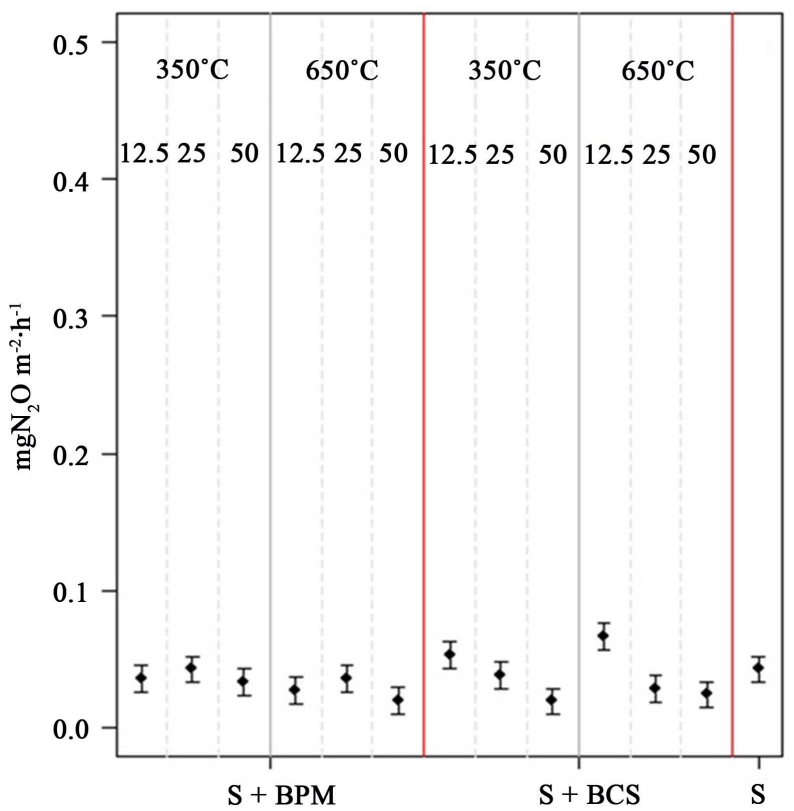

(b)

Figure 3. Emission of $\mathrm{N}_{2} \mathrm{O}$ from a tropical sandy soil (S) amended with a) raw materials: poultry manure (S + PM) and sugar cane straw $(S+C S)$; and b) biochars: biochar poultry manure $(S+B P M)$ and biochar of sugar cane straw $(S+B C S)$.

emitted higher levels of $\mathrm{CO}_{2}$, and showed a greater variation among rates, despite no statistical difference between the poultry manure biochar (BPM) rates of 25 and $50 \mathrm{Mg} \cdot \mathrm{ha}^{-1}$, regardless pyrolysis temperature. The BPM also presented a statistical difference between the two pyrolysis temperatures. The sugar cane straw biochar (BCS) had a small amplitude of gas emissions between treatments, with little or no significative response.

\subsection{Application Rate}

The lowest rate $\left(12.5 \mathrm{Mg} \cdot \mathrm{ha}^{-1}\right)$ of both raw materials showed higher emissions of $\mathrm{CO}_{2}$ than the control (Figure 1(a)). As expected, there was an increase in $\mathrm{CO}_{2}$ and $\mathrm{CH}_{4}$ emissions (Figure 1(a) and Figure 2(a)) with increased application rate, such that the highest rate of both raw materials $\left(50 \mathrm{Mg} \cdot \mathrm{ha}^{-1}\right)$ provided the greatest emission of these gases. For $\mathrm{CH}_{4}$ emissions (Figure 2(a)), only the application of 25 and $50 \mathrm{Mg} \cdot \mathrm{ha}^{-1}$ of SC resulted in higher emissions than the control. For $\mathrm{N}_{2} \mathrm{O}$ (Figure 3(a)), only the application of $25 \mathrm{Mg} \cdot \mathrm{ha}^{-1}$ of PM resulted in a superior emission compared to the control.

The intermediate rate of applied $\mathrm{BCS}$ had higher $\mathrm{CO}_{2}$ emissions than the other rates, at both pyrolysis temperatures (Figure $1(\mathrm{~b})$ ). This pattern, also observed for $\mathrm{CH}_{4}$ emissions (Figure 2(b)), had the largest emission values observed with the $25 \mathrm{Mg} \cdot \mathrm{ha}^{-1}$ rate, regardless biochar raw material source or pyrolysis temperature. Both observations are in agreement with the higher MBN values found for this rate (Table 3 ).

The application of BCS at the lowest rate resulted in a higher emission than the control treatment, regardless of the pyrolysis temperature (Figure 3(b)). 
Table 3. Effects of raw materials, biochar application rates and pyrolisis temperature on $\mathrm{C}$ and $\mathrm{N}$ in a tropical sandy soil.

\begin{tabular}{|c|c|c|c|c|c|c|c|c|c|c|c|c|c|}
\hline \multirow{2}{*}{ Treatment } & Dose & \multicolumn{2}{|l|}{$\mathrm{MBC}^{(1)}$} & \multicolumn{2}{|l|}{$\mathrm{MBN}^{(2)}$} & \multicolumn{2}{|l|}{$C^{(3)}$} & \multicolumn{2}{|l|}{$\mathrm{N}^{(3)}$} & \multirow[t]{2}{*}{$\mathrm{C} / \mathrm{N}$} & \multicolumn{3}{|c|}{$\begin{array}{l}\text { Cmic: } \\
\text { Ctot }^{(4)}\end{array}$} \\
\hline & Mg.ha ${ }^{-1}$ & & & & & \multicolumn{4}{|c|}{$\mathrm{mg} \mathrm{L}^{-1}$} & & & \multicolumn{2}{|l|}{$\%$} \\
\hline \multicolumn{14}{|c|}{ Raw Materials } \\
\hline \multirow{4}{*}{$\mathrm{S}+\mathrm{PM}$} & 12.50 & 38.78 & $\mathrm{Cb}$ & 6.73 & $\mathrm{Ab}$ & 0.75 & $\mathrm{Bb}$ & 0.06 & $\mathrm{Ba}$ & 12.64 & $\mathrm{Aa}$ & 0.19 & $\mathrm{Ca}$ \\
\hline & 25.00 & 72.69 & $\mathrm{Ba}$ & 20.30 & $\mathrm{Ab}$ & 0.90 & $\mathrm{Abb}$ & 0.08 & Aba & 11.73 & $\mathrm{Ab}$ & 0.80 & $\mathrm{Ba}$ \\
\hline & 50.00 & 170.25 & $\mathrm{Aa}$ & 25.67 & $\mathrm{Aa}$ & 1.12 & $\mathrm{Ab}$ & 0.11 & $\mathrm{Aa}$ & 10.41 & $\mathrm{Ab}$ & 1.53 & $\mathrm{Aa}$ \\
\hline & 12.50 & 73.71 & $\mathrm{Aa}$ & 29.84 & $\mathrm{Ba}$ & 0.95 & $\mathrm{Ca}$ & 0.06 & $\mathrm{Aa}$ & 17.27 & $\mathrm{Ba}$ & 0.82 & $\mathrm{Aa}$ \\
\hline \multirow[t]{2}{*}{$\mathrm{S}+\mathrm{CS}$} & 25.00 & 36.32 & $\mathrm{Cb}$ & 41.49 & $\mathrm{Aa}$ & 1.19 & $\mathrm{Ba}$ & 0.05 & $\mathrm{Ab}$ & 26.63 & $\mathrm{Aa}$ & 0.31 & $\mathrm{Aa}$ \\
\hline & 50.00 & 54.98 & $\mathrm{Bb}$ & 15.62 & $\mathrm{Ba}$ & 1.91 & $\mathrm{Aa}$ & 0.07 & $\mathrm{Ab}$ & 27.96 & $\mathrm{Aa}$ & 0.29 & $\mathrm{Ab}$ \\
\hline \multicolumn{14}{|c|}{ Biochar } \\
\hline \multirow{3}{*}{$\begin{array}{c}\mathrm{S}+\mathrm{BPM} \\
350^{\circ} \mathrm{C}\end{array}$} & 12.50 & 170.49 & $\mathrm{Ca}$ & 93.19 & $\mathrm{Ba}$ & 0.93 & $\mathrm{Ba}$ & 0.06 & $\mathrm{Aa}$ & 15.12 & $\mathrm{Aa}$ & 1.85 & $\mathrm{Aa}$ \\
\hline & 25.00 & 204.04 & $\mathrm{Ba}$ & 124.95 & Aa & 1.22 & $\mathrm{Ba}$ & 0.08 & Aa & 16.94 & Aa & 1.68 & $\mathrm{Aa}$ \\
\hline & 50.00 & 223.96 & $\mathrm{Aa}$ & 39.95 & $\mathrm{Cb}$ & 1.79 & Aa & 0.12 & $\mathrm{Aa}$ & 16.45 & $\mathrm{Aa}$ & 1.29 & $\mathrm{Aa}$ \\
\hline \multirow{3}{*}{$\begin{array}{c}\mathrm{S}+\mathrm{BPM} \\
650^{\circ} \mathrm{C}\end{array}$} & 12.50 & 190.16 & $\mathrm{Ba}$ & 101.16 & $\mathrm{Bb}$ & 0.95 & $\mathrm{Ca}$ & 0.06 & $\mathrm{Aa}$ & 16.67 & $\mathrm{Ba}$ & 2.00 & $\mathrm{Aa}$ \\
\hline & 25.00 & 116.51 & $\mathrm{Ca}$ & 112.13 & $\mathrm{Aa}$ & 1.16 & $\mathrm{Ba}$ & 0.07 & $\mathrm{Aa}$ & 17.54 & $\mathrm{Ba}$ & 1.03 & $\mathrm{Ba}$ \\
\hline & 50.00 & 213.99 & $\mathrm{Aa}$ & 94.46 & $\mathrm{Ba}$ & 1.70 & $\mathrm{Aa}$ & 0.09 & $\mathrm{Aa}$ & 21.15 & $\mathrm{Aa}$ & 1.27 & Aba \\
\hline \multirow{3}{*}{$\begin{array}{c}\mathrm{S}+\mathrm{BCS} \\
350^{\circ} \mathrm{C}\end{array}$} & 12.50 & 127.93 & $\mathrm{Aa}$ & 72.24 & $\mathrm{Aa}$ & 1.25 & $\mathrm{Ca}$ & 0.08 & $\mathrm{Aa}$ & 16.16 & $\mathrm{Ba}$ & 1.04 & $\mathrm{Aa}$ \\
\hline & 25.00 & 106.28 & $\mathrm{Ba}$ & 76.91 & Aa & 1.92 & $\mathrm{Ba}$ & 0.12 & $\mathrm{Aa}$ & 16.76 & $\mathrm{Ba}$ & 0.58 & $\mathrm{Ba}$ \\
\hline & 50.00 & 126.04 & $\mathrm{Aa}$ & 63.09 & $\mathrm{Aa}$ & 2.80 & $\mathrm{Aa}$ & 0.11 & $\mathrm{Aa}$ & 26.59 & $\mathrm{Aa}$ & 0.41 & $\mathrm{Ba}$ \\
\hline \multirow{3}{*}{$\begin{array}{c}\mathrm{S}+\mathrm{BCS} \\
650^{\circ} \mathrm{C}\end{array}$} & 12.50 & 103.41 & $\mathrm{Ab}$ & 49.87 & $\mathrm{Ba}$ & 1.34 & $\mathrm{Ba}$ & 0.07 & $\mathrm{Aa}$ & 22.55 & $\mathrm{Ba}$ & 0.77 & $\mathrm{Aa}$ \\
\hline & 25.00 & 85.58 & $\mathrm{Ba}$ & 63.24 & $\mathrm{Aa}$ & 1.78 & $\mathrm{Ba}$ & 0.07 & $\mathrm{Aa}$ & 28.70 & $\mathrm{Ba}$ & 0.50 & $\mathrm{ABa}$ \\
\hline & 50.00 & 111.84 & $\mathrm{Aa}$ & 59.65 & Aba & 3.18 & $\mathrm{Aa}$ & 0.09 & $\mathrm{Aa}$ & 37.31 & $\mathrm{Aa}$ & 0.36 & $\mathrm{Ba}$ \\
\hline
\end{tabular}

S + PM: Soil + Poltry Manure; S + CS: Soil + Case Straw; S + BPM $350^{\circ} \mathrm{C}$ : Soil + Biochar of Poultry Manure pyrolysed at $350^{\circ} \mathrm{C} ; \mathrm{S}+\mathrm{BPM} 650^{\circ} \mathrm{C}$ : Soil + Biochar of Poultry Manure pyrolysed at $650^{\circ} \mathrm{C} ; \mathrm{S}+\mathrm{BCS} 350^{\circ} \mathrm{C}$ : Soil + Biochar of Case Straw pyrolysed at $350^{\circ} \mathrm{C} ; \mathrm{S}+\mathrm{BCS} 650^{\circ} \mathrm{C}$ : Soil + Biochar of Case Straw pyrolysed at $650^{\circ} \mathrm{C}$; ${ }^{(1)}$ Microbial Biomass Carbon; ${ }^{(2)}$ Microbial Biomass Nitrogen; ${ }^{(3)}$ Total $\mathrm{C}$ and $\mathrm{N}$ of the treatments; ${ }^{(4)}$ Ratio of Microbial Biomass C/Total C. Averages followed by the same capital letter refer to the comparison among doses of the same treatment; Averages followed by the same lowercase letters refer to the comparison of the same dose among treatments.

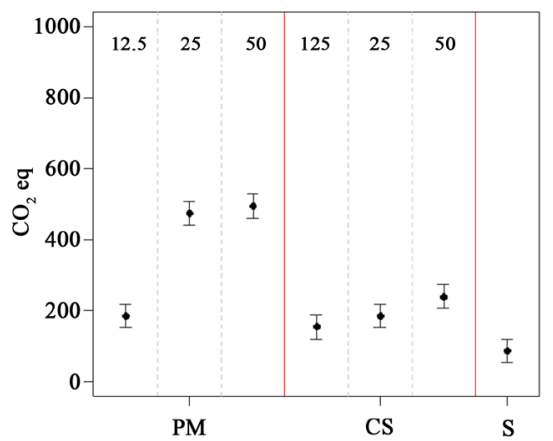

(a)

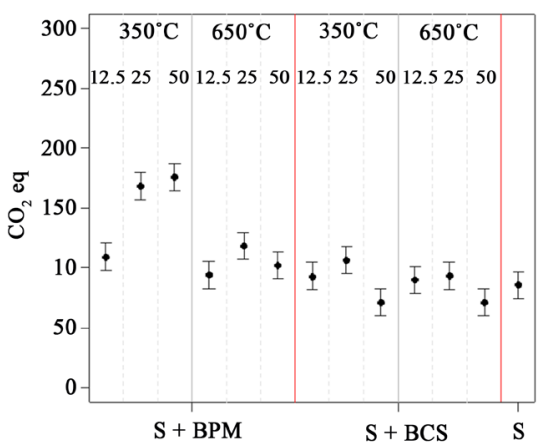

(b)

Figure 4. Emissions in $\mathrm{CO}_{2}$ equivalent from a tropical sandy soil (S) amended with (a) raw materials: poultry manure $(S+P M)$ and sugar cane straw $(S+C S)$; and (b) biochars: biochar poultry manure $(S+B P M)$ and biochar of sugar cane straw $(S+B C S)$. 
Emission values for $\mathrm{N}_{2} \mathrm{O}$ decreased with the increasing application rates above 12.5 Mg.ha ${ }^{-1}$. No statistical differences were detected for $\mathrm{N}_{2} \mathrm{O}$ emissions by BPM, regardless the applied rate or pyrolysis temperature (Figure 3(b)).

\subsection{Pyrolysis Temperatures}

When the pyrolysis temperatures were compared for BPM (Figure 1(b)), the higher GHG emission levels at $350^{\circ} \mathrm{C}$ were to be expected. For BCS the pyrolysis temperature did not affect $\mathrm{CO}_{2}$ emission (Figure 1(b)), since no significant differences were observed between temperatures, comparing the same rate.

The $\mathrm{CO}_{2}$ emissions for the soil without the addition of residue (control) did not significantly differ from the emissions obtained from the soil after the BCS addition, regardless of the applied rate or pyrolysis temperature (Figure 1(b)). When the addition of SC (Figure 1(a)) is compared to its respective biochar, produced at $350^{\circ} \mathrm{C}$ (Figure $1(\mathrm{~b})$ ), the emissions were 1.89, 1.90 and 3.60 times higher for non-pyrolyzed material at the rates $12.5,25$ and $50 \mathrm{Mg} \cdot \mathrm{ha}^{-1}$, respectively. When compared to the biochar produced at $650^{\circ} \mathrm{C}$ the non-pyrolyzed material produced emissions 2.19, 2.13 and 3.82 times higher, at the same rates. For BPM the same pattern was observed. Although the emissions were slightly higher than the control, when compared to the raw material, the non-pyrolyzed form showed emissions 1.36, 2.58 and 3.03 times higher than the biochar produced at $350^{\circ} \mathrm{C}$, for the rates $12.5,25$ and $50 \mathrm{Mg} \cdot \mathrm{ha}^{-1}$, respectively. Using a pyrolysis temperature of $650^{\circ} \mathrm{C}$, the emissions from the raw materials were 1.67, 3.95 and 5.78 times higher, at the same rates.

\section{5. $\mathrm{CO}_{2}$ Equivalent}

The same pattern obtained in $\mathrm{CO}_{2}$ emissions (Figure 1) was observed for $\mathrm{SC}$ and biochars (BPM and BCS) at the standard unit (Figure 4), regardless the different treatments. For poultry manure as a raw material, the highest rates (25 and 50 $\mathrm{Mg} \cdot \mathrm{ha}^{-1}$ ) were not statistically different, which does not occur for $\mathrm{CO}_{2}$ emission (Figure 1(a)).

\section{Discussion}

The largest emission of GHG, observed during the first 15 days, was slowly reduced. From day 36, treatments were no longer statistically different from the control, confirming that the gas emissions had already stabilized and no longer needed to be collected (Figure 5). The gas sampling continued for more 103 days, in order to confirm that the microbiota had already stabilized and would not have a new peak of emission, as sometimes reported by few authors [38]; [39] and [40].

The higher emissions by both raw materials, relative to the control, demonstrates that even small quantities of applied feedstocks increase $\mathrm{CO}_{2}$ emissions (Figure 1(a)). The higher values of $\mathrm{CO}_{2}$ emissions by the addition of PM, non- 


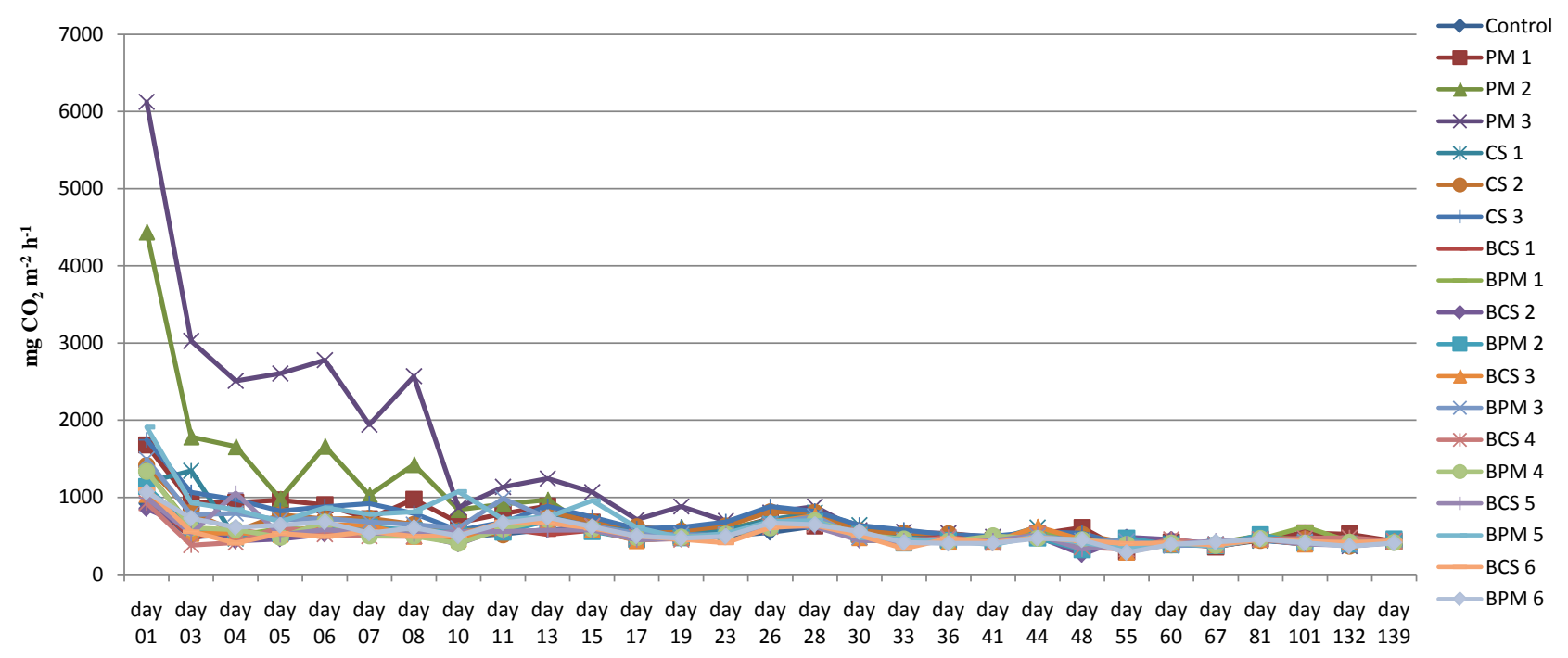

Figure 5. Flow of $\mathrm{CO}_{2}$ measured in the chamber during 139 days. Control = Only soil; PM $1=$ poultry manure dose $12.5 \mathrm{Mg} \cdot \mathrm{ha}{ }^{-1}$; PM 2 = poultry manure dose $25 \mathrm{Mg} \cdot \mathrm{ha}^{-1}$; PM 3 = poultry manure dose $50 \mathrm{Mg} \cdot \mathrm{ha}^{-1}$; CS 1 = Cane Straw dose $12.5 \mathrm{Mg} \cdot \mathrm{ha}{ }^{-1}$; CS 2 = Cane Straw dose $25 \mathrm{Mg} \cdot \mathrm{ha}^{-1}$; CS 3 = Cane Straw dose $50 \mathrm{Mg} \cdot \mathrm{ha}^{-1}$; BCS 1 = Biochar Cane Straw dose $12.5 \mathrm{Mg} \cdot \mathrm{ha}^{-1} \mathrm{Temperature} \mathrm{of}$ pyrolysis $350^{\circ} \mathrm{C}$; BPM 1 = Biochar poultry manure dose $12.5 \mathrm{Mg} \cdot \mathrm{ha}^{-1}$ Temperature of pyrolysis $350^{\circ} \mathrm{C}$; BCS $2=$ Biochar Cane Straw dose $12.5 \mathrm{Mg} \mathrm{ha}^{-1}$ Temperature of pyrolysis $650^{\circ} \mathrm{C}$; BPM 2 = Biochar poultry manure dose $12.5 \mathrm{Mg} \cdot \mathrm{ha}^{-1} \mathrm{Temperature}$ of pyrolysis $650^{\circ} \mathrm{C}$; BCS $3=$ Biochar Cane Straw dose $25 \mathrm{Mg} \cdot \mathrm{ha}^{-1}$ Temperature of pyrolysis $350^{\circ} \mathrm{C}$; BPM $3=$ Biochar poultry manure dose $25 \mathrm{Mg} \cdot \mathrm{ha}^{-1}$ Temperature of pyrolysis $350^{\circ} \mathrm{C}$; BCS 4 = Biochar Cane Straw dose $25 \mathrm{Mg} \cdot \mathrm{ha}^{-1} \mathrm{Temperature} \mathrm{of} \mathrm{pyrolysis} 650^{\circ} \mathrm{C}$; BPM 4 = Biochar poultry manure dose $25 \mathrm{Mg} \cdot \mathrm{ha}^{-1}$ Temperature of pyrolysis $650^{\circ} \mathrm{C}$; BCS $5=$ Biochar Cane Straw dose $50 \mathrm{Mg} \cdot \mathrm{ha}^{-1}$ Temperature of pyrolysis $350^{\circ} \mathrm{C}$; BPM $5=$ Biochar poultry manure dose $50 \mathrm{Mg} \cdot \mathrm{ha}^{-1}$ Temperature of pyrolysis $350^{\circ} \mathrm{C}$; $\mathrm{BCS} 6=$ Biochar Cane Straw dose $50 \mathrm{Mg} \cdot \mathrm{ha}^{-1} \mathrm{Temperature}$ of pyrolysis $650^{\circ} \mathrm{C}$; BPM 6 = Biochar poultry manure dose $50 \mathrm{Mg} \cdot \mathrm{ha}^{-1} \mathrm{Temper}-$ ature of pyrolysis $650^{\circ} \mathrm{C}$.

pyrolysed or pyrolysed, than with applied SC (Figure 1(a) and Figure 1(b)), suggests greater stability of cane straw and a less drastic effect on the environment, from GHG emissions point of view.

For the raw materials, the $\mathrm{CO}_{2}$ and $\mathrm{CH}_{4}$ emissions (Figure 1(a) and Figure 2(a)) increased with increasing application rates. According to [41], the waste management is one of the principle causes of GHG emissions in the agricultural environment, which corroborates the loss of $\mathrm{C}$ and $\mathrm{N}$ after the application of these residues to soil. The higher emission of $\mathrm{N}_{2} \mathrm{O}$ (Figure 3(a)) for the 25 $\mathrm{Mg} \cdot \mathrm{ha}^{-1}$ rate of applied PM (the only one that differs statistically from the control) was attributed to a combination of oxygen and $\mathrm{C}$ availability. The hypothesis, based on a perfect environment, which combines oxygen availability and labile $\mathrm{C}$ for the microbiota, was found on the intermediate rate. However, this assumption was not confirmed by the values found in the microbial biomass (Table 3), perhaps because these data were obtained only at the end of the experiment, when the GHG emissions were already stable.

We could imply that the absence of statistical difference between the BPM rates of 25 and $50 \mathrm{Mg} \cdot h \mathrm{a}^{-1}$, for both pyrolysis temperatures, is due to a "maximum point", above which there is no effect on $\mathrm{CO}_{2}$ emission. According to [27], the flow of $\mathrm{CO}_{2}$ presents higher relative reductions with application of raters 
lower than $20 \mathrm{Mg} \cdot \mathrm{ha}^{-1}$ of biochar, while the total organic carbon increases at applied rates from 20 to $40 \mathrm{Mg} \cdot \mathrm{ha}^{-1}$. This is due to an increase in microbial biomass of $50 \%$ in rates lower than $20 \mathrm{Mg} \cdot \mathrm{ha}^{-1}$, in contrast to an increase of only $8 \%$ in 20 to $40 \mathrm{Mg} \cdot \mathrm{ha}^{-1}$ rates. The negative effect of applying high rates of biochar to the soil microbiota is justified by the high $\mathrm{C} / \mathrm{N}$ ratio of the applied material, inducing $\mathrm{N}$ immobilization and reducing microbial activity (Table 3 ).

The higher emissions of $\mathrm{CO}_{2}$ and $\mathrm{CH}_{4}$ (Figure 1(b) and Figure 2(b)) from the intermediate rate $\left(25 \mathrm{Mg} \cdot \mathrm{ha}^{-1}\right)$ of the $\mathrm{BCS}$, are in agreement with the higher MBN values for these treatments (Table 3 ) and was attributed to a more beneficial environment at this application rate. [42] and [43] also found a similar pattern in their studies, with application of three different rates of biochar. These authors assumed that the higher gas emission values for the intermediate rate could be due to a combined $\mathrm{C} / \mathrm{N}$ ratio, coming from the original soil and the biochar. Considering that the soil's $\mathrm{C} / \mathrm{N}$ ratio will prevail in the lowest applied rate whereas the biochar's $\mathrm{C} / \mathrm{N}$ ratio will prevail at the highest rate, it is plausible to assume that on the intermediate rate there will be an intermediate $\mathrm{C} / \mathrm{N}$ ratio providing an optimal environment for microbiological growth. Although we did not find a statistical difference for all treatments, we can observe this pattern occurring among treatments, where the $\mathrm{C} / \mathrm{N}$ ratio of the intermediate application rate approaches the average of the extreme rates (Table 3 ).

The higher emissions of GHG for BPM pyrolysed at $350^{\circ} \mathrm{C}$ was due to the maintenance of the original characteristics of the material. With pyrolysis temperature at $650^{\circ} \mathrm{C}$, aliphatic chains, aromatic rings and elemental composition of $\mathrm{C}, \mathrm{N}$ and $\mathrm{O}$ are reduced, making the biochar more recalcitrant [44]. Many characteristics, such as ash content, $\mathrm{CEC}$ and $\mathrm{C} / \mathrm{N}$ ratio, vary according to the raw material [45] and [46], which justifies similar $\mathrm{CO}_{2}$ emission values for the $\mathrm{BCS}$, whether pyrolyzed at $350^{\circ} \mathrm{C}$ or $650^{\circ} \mathrm{C}$. The $\mathrm{BCS}$ material is already highly recalcitrant, producing a biochar with lower ash content, lower nutrient diversity and greater surface area [47]. We can also infer that BPM pyrolysed at $650^{\circ} \mathrm{C}$ is more efficient in GHGs mitigation, since this procedure will increase surface area, ash content and stability of the biochar [48] and [49], reducing, $\mathrm{CO}_{2}$ emissions, mostly at higher applied rates. In a study with biochar from sugar cane straw, [50] observed an $80 \%$ loss of $\mathrm{N}$ from the material, using a pyrolysis temperature of $750^{\circ} \mathrm{C}$. These authors reached a $\mathrm{C} / \mathrm{N}$ ratio of 47 after using pyrolysis at $450^{\circ} \mathrm{C}$, whereas the $\mathrm{C} / \mathrm{N}$ ratio was 280 when pyrolyzed at $750^{\circ} \mathrm{C}$. They also observed a reduction in the $\mathrm{H} / \mathrm{C}$ and $\mathrm{O} / \mathrm{C}$ ratios and an increase in the ash content with the increase in the pyrolysis temperature. This suggests an increase in aromatic structures and degree of carbonization, when compared to the raw material. The similarity in $\mathrm{CO}_{2}$ emissions between the pyrolysis temperatures of BCS (Figure $1(b)$ ) can be attributed to the nature of the raw material, allowing the inference that there is no advantage in GHG mitigation when pyrolyzing material such as straws at temperatures above $350^{\circ} \mathrm{C}$.

The lower $\mathrm{CO}_{2}$ emission values of biochars relative to the raw materials, in the 
same applied rate and pyrolysis temperature (for the biochars), allowed the conclusion that the production of biochars from these raw materials is a viable solution for adding these residues to soil, without an increase in GHG emissions. [51] observed a decomposition of $56 \%$ of the $\mathrm{C}$ added as wheat straw after 84 days, while over the same period, only $2.8 \%$ of the $C$ from its respective biochar had decomposed.

However, regardless the higher $\mathrm{N}_{2} \mathrm{O}$ emission for the lower rate of BCS application at either pyrolysis temperature (Figure $3(\mathrm{~b})$ ), relative to the control, is probably due to the formation of aerobiotic sites in the extremely porous biochar. This observation leads us to think that increases in this biochar application would increase the availability of oxygen, reducing the anaerobic environment and $\mathrm{N}_{2} \mathrm{O}$ emissions. No statistical difference was observed for $\mathrm{N}_{2} \mathrm{O}$ emissions from BPM, regardless the applied rate or pyrolysis temperature (Figure 3(b)). We assume that this material reduces the chance of anaerobiosis through a higher amount of micropores than the BCS, and its lower $\mathrm{C} / \mathrm{N}$ ratio (Table 3 ) limits the amount of soluble $\mathrm{C}$ available for microbiota performance.

The $\mathrm{CO}_{2}$ equivalent graph (Figure 4) indicates there are few differences between the combined emission of the three gases and $\mathrm{CO}_{2}$ emissions alone. In soils that are not flooded or for any reason have hypoxic/anoxic condition, there are no expressive emissions of $\mathrm{CH}_{4}$ and $\mathrm{N}_{2} \mathrm{O}$. Even though we found statistical differences among some treatments of these two gases, the emission were small. The lack of differences between the highest rates of PM (Figure 4(a)), differently from $\mathrm{CO}_{2}$ emissions alone (Figure $1(\mathrm{a})$ ), is due to the high emission of $\mathrm{N}_{2} \mathrm{O}$ in the intermediate rate $\left(25 \mathrm{Mg} \cdot \mathrm{ha}^{-1}\right)$ that raised the value close to the rate of 50 $\mathrm{Mg} \cdot \mathrm{ha}^{-1}$ when added into the standard unit. Even though the initial value of $\mathrm{N}_{2} \mathrm{O}$ emission in $25 \mathrm{Mg} \cdot \mathrm{ha}^{-1}$ rate is low $\left(0.23 \mathrm{mg} \mathrm{N}_{2} \mathrm{O} \mathrm{m}^{-2} \cdot \mathrm{h}^{-1}\right)$, its GWP is high (298); when calculated for $\mathrm{CO}_{2 \mathrm{eq}}$ (Equation (3)) this contribution is amplified.

Agricultural production, since 1970, has grown 118\% and livestock production $102 \%$, with an increase in emissions of 65 and 119\%, per harvest and per head, respectively [19]. This implies that a secure environmental destination has to be found, for plant and animal residues.

\section{Conclusion}

The biochar from poultry manure causes higher GHG emissions than the biochar produced from sugar cane straw, but both cause a significant reduction in the $\mathrm{CO}_{2 \mathrm{eq}}$ emission and represent an environmentally secure way of depositing residual material in the field. For the poultry manure biochar, higher pyrolysis temperatures have a significant effect in reducing GHG emissions, however this was not observed for the biochar produced from sugar cane straw thus it is much more recalcitrant and is not affected by different managements. There is a greater emission of the three gases when applying the intermediate rate, demonstrated by a greater microbial biomass in this treatment, nevertheless, the cause is still not well known and deserves to be furthered studied. 


\section{References}

[1] Lamb, A., Green, R., Bateman, I., Broadmeadow, M., Bruce, T., Burney, J. and Goulding, K. (2016) The Potential for Land Sparing to Offset Greenhouse Gas Emissions from Agriculture. Nature Climate Change, 6, 488-492.

https://doi.org/10.1038/nclimate2910

[2] Cotrufo, M.F., Soong, J.L., Horton, A.J., Campbell, E.E., Haddix, M.L., Wall, D.H. and Parton, W.J. (2015) Formation of Soil Organic Matter via Biochemical and Physical Pathways of Litter Mass Loss. Nature Geoscience, 8, 776-779. https://doi.org/10.1038/ngeo2520

[3] Cardozo, N.P., Bordonal, R.D.O. and La Scala, N. (2016) Greenhouse Gas Emission Estimate in Sugarcane Irrigation in Brazil: Is It Possible to Reduce It, and Still Increase Crop Yield? Journal of Cleaner Production, 112, 3988-3997. https://doi.org/10.1016/j.jclepro.2015.09.040

[4] Madari, B.E., de Freitas Maia, C.M.B. and Novotny, E.H. (2012) Preface: Context and Importance of Biochar Research. Pesquisa Agropecuária Brasileira, 47, 1-2. https://doi.org/10.1590/S0100-204X2012000500001

[5] Agegnehu, G., Bass, A.M., Nelson, P.N. and Bird, M.I. (2016) Benefits of Biochar, compost and Biochar-Compost for Soil Quality, Maize Yield and Greenhouse Gas Emissions in a Tropical Agricultural Soil. Science of the Total Environment, 543, 295-306. https://doi.org/10.1016/j.scitotenv.2015.11.054

[6] Smith, P. (2016) Soil Carbon Sequestration and Biochar as Negative Emission Technologies. Global Change Biology, 22, 1315-1324. https://doi.org/10.1111/gcb.13178

[7] Verheijen, F., Jeffery, S., Bastos, A.C., Van Der Velde, M. and Diafas, I. (2010) Biochar Application to Soils: A Critical Review of Effects on Soil Properties, Processes and Functions. JRC Scientific and technical Report.

[8] Sánchez-García, M., Sánchez-Monedero, M.A., Roig, A., López-Cano, I., Moreno, B., Benitez, E. and Cayuela, M.L. (2016) Compost vs Biochar Amendment: A Two-Year Field Study Evaluating Soil C Build-Up and N Dynamics in an Organically Managed Olive Crop. Plant Soil, 408, 1-14. https://doi.org/10.1007/s11104-016-2794-4

[9] Atkinson, C.J., Fitzgerald, J.D. and Hipps, N.A. (2010) Potential Mechanisms for Achieving Agricultural Benefits from Biochar Application to Temperate Soils: A Review. Plant Soil, 337, 1-18. https://doi.org/10.1007/s11104-010-0464-5

[10] Lehmann, J. and Joseph, S. (2015) Biochar for Environmental Management: Science, Technology and Implementation. Routledge.

[11] Puga, A.P., Abreu, C.A., Melo, L.C.A., Paz-Ferreiro, J. and Beesley, L. (2015) Cadmium, Lead, and Zinc Mobility and Plant Uptake in a Mine Soil Amended with Sugarcane Straw Biochar. Environmental Science and Pollution Research, 22, 1760617614. https://doi.org/10.1007/s11356-015-4977-6

[12] Teichmann, I. (2014) Technical Greenhouse-Gas Mitigation Potentials of Biochar Soil Incorporation in Germany. DIW Berlin Discussion Paper, No.1406, X p. 92. https://doi.org/10.2139/ssrn.2487765

[13] Intergovernmental Panel on Climate Change (2015) Climate Change 2014: Mitigation of Climate Change (Vol. 3). Cambridge University Press, Cambridge.

[14] CONAB (2013) Companhia Nacional de Abastecimento Acompanhamento da safra Brasileira: Cana de açúcar. Agosto Conab, Brasília, X p.19. 
[15] Castro, L.T., Fava Neves, M. and Fava Scare, R. (2015) Eficiência de Representação das Associações de Produtores de Cana-de-açúcar no Brasil. Organizações Rurais \& Agroindustriais, 17, 383-397.

[16] Orlando, F.J., Carmello, Q.A.C., Pexe, C.A. and Glória, A.M. (1994) Adubação de Soqueira de Cana-de-açúcar sob dois tipos de Despalha: Cana Crua x Cana Queimada. STAB-Açúcar, Álcool e Subprodutos, Piracicaba, 12, 7-11.

[17] Goldemberg, J., Nigro, F.E.B. and Coelho, S.T. (2008) Bioenergia no Estado de São Paulo: Situação Atual, Perspectivas e Propostas. Imprensa Oficial do Estado de São Paulo, São Paulo, X p. 152.

[18] Melo, L.C.A., Puga, A.P., Coscione, A.R., Beesley, L., Abreu, C.A. and Camargo, O.A. (2016) Sorption and Desorption of Cadmium and Zinc in Two Tropical Soils Amended with Sugarcane-Straw-Derived Biochar. Journal of Soils and Sediments, 16, 226-234. https://doi.org/10.1007/s11368-015-1199-y

[19] Bennetzen, E.H., Smith, P. and Porter, J.R. (2016) Agricultural Production and Greenhouse Gas Emissions from World Regions - The Major Trends over 40 Years. Global Environmental Change, 37, 43-55. https://doi.org/10.1016/j.gloenvcha.2015.12.004

[20] Vieira, A.S. (2015) Gestão Ambiental: Uma Visão Multidisciplinar. Clube de Autores, São Paulo, X p. 285.

[21] Gaunt, J. and Cowie, A. (2009) Biochar, Greenhouse Gas Accounting and Emissions Trading. In: Lehmann, J. and Joseph, S., Eds., Biochar for Environmental Management. Science and Technology, Earthscan, London, 317-340.

[22] Woolf, D., Amonette, J.E., Street-Perrott, F.A., Lehmann, J. and Joseph, S. (2010) Sustainable biochar to Mitigate Global Climate Change. Nature Communications, 1, 56. https://doi.org/10.1038/ncomms1053

[23] Hammond, J., Shackley, S., Sohi, S. and Brownsort, P. (2011) Prospective Life Cycle Carbon Abatement for Pyrolysis Biochar Systems in the UK. Energy Policy, 39, 2646-2655. https://doi.org/10.1016/j.enpol.2011.02.033

[24] Roberts, K.G., Gloy, B.A., Joseph, S., Scott, N.R. and Lehmann, J. (2010) Life Cycle Assessment of Biochar Systems: Estimating the Energetic, Economic, and Climate Change Potential. Environmental Science \& Technology, 44, 827-833. https://doi.org/10.1021/es902266r

[25] Wu, F., Jia, Z., Wang, S., Chang, S.X. and Startsev, A. (2013) Contrasting Effects of Wheat Straw and Its Biochar on Greenhouse Gas Emissions and Enzyme Activities in a Chernozemic Soil. Biology and Fertility of Soils, 49, 555-565. https://doi.org/10.1007/s00374-012-0745-7

[26] Rondon, M.A., Molina, D., Hurtado, M., Ramirez, J., Lehmann, J., Major, J. and Amezquita, E. (2006) Enhancing the Productivity of Crops and Grasses while Reducing Greenhouse Gas Emissions through Bio-Char Amendments to Unfertile Tropical Soils. 18th World Congress of Soil Science, 9-15.

[27] Liu, Y., Yang, M., Wu, Y., Wang, H., Chen, Y. and Wu, W. (2011) Reducing CH4 and CO2 Emissions from Waterlogged Paddy Soil with Biochar. Journal of Soils and Sediments, 11, 930-939. https://doi.org/10.1007/s11368-011-0376-x

[28] EMBRAPA (2006) Sistema Brasileiro de Classificação de Solos. Centro Nacional de Pesquisa de Solos, Rio de Janeiro.

[29] Novais, R.F. and Smith, T.J. (1999) Fósforo em Solo e Planta em Condições Tropicais. Viçosa: UFV-DPS, 62-64. 
[30] Conz, R.F. (2015) Caracterização de Matérias-Primas e Biochars Para Aplicação na Agricultura. Master's Thesis, University of São Paulo/ESALQ, São Paulo, X p. 135.

[31] Crombie, K., Mašek, O., Cross, A. and Sohi, S. (2015) Biochar-Synergies and TradeOffs between Soil Enhancing Properties and C Sequestration Potential. GCB Bioenergy, 7, 1161-1175. https://doi.org/10.1111/gcbb.12213

[32] Reichardt, K. (1988) Capacidade de Campo. Revista Brasileira de Ciência do Solo, 12, 211-216.

[33] ASTM (2008) Standard Test Methods for Instrumental Determination of Carbon, Hydrogen, and Nitrogen in Laboratory Samples of Coal and Coke. American Society for Testing and Materials (ASTM), Pennsylvania.

[34] Tedesco, M.J., Gianello, C., Bissani, C.A., Bohnen, H. and Volkweiss, S.J. (1995) Análise de Solo, Plantas e Outros Materiais. Boletim Técnico, Universidade Federal do Rio Grande do Sul, Porto Alegre. 5, 174.

[35] Sánchez-Monedero, M.A., Serramiá, N., Civantos, C.G.O., Fernández-Hernández, A. and Roig, A. (2010) Greenhouse Gas Emissions during Composting of TwoPhase Olive Mill Wastes with Different Agroindustrial by-Products. Chemosphere, 81, 18-25. https://doi.org/10.1016/j.chemosphere.2010.07.022

[36] Wang, W., Wu, X., Chen, A., Xie, X., Wang, Y. and Yin, C. (2016) Mitigating Effects of Ex Situ Application of Rice Straw on CH4 and N2O Emissions from Paddy-Upland Coexisting System. Scientific Reports, 6, Article ID: 37402.

[37] The R Core Team (2015) R: A Language and Environment for Statistical Computing, Vienna.

[38] Gomez, J.D., Denef, K., Stewart, C.E., Zheng, J. and Cotrufo, M.F. (2014) Biochar Addition Rate Influences Soil Microbial Abundance and Activity in Temperate Soils. European Journal of Soil Science, 65, 28-39. https://doi.org/10.1111/ejss.12097

[39] Budai, A., Rasse, D.P., Lagomarsino, A., Lerch, T.Z. and Paruch, L. (2016) Biochar Persistence, Priming and Microbial Responses to Pyrolysis Temperature Series. Biology and Fertility of Soils, 52, 749-761. https://doi.org/10.1007/s00374-016-1116-6

[40] Jiang, X., Denef, K., Stewart, C.E. and Cotrufo, M.F. (2016) Controls and Dynamics of Biochar Decomposition and Soil Microbial Abundance, Composition, and Carbon Use Efficiency during Long-Term Biochar-Amended Soil Incubations. Biology and Fertility of Soils, 52, 1-14. https://doi.org/10.1007/s00374-015-1047-7

[41] Pratt, C., Redding, M., Hill, J., Shilton, A., Chung, M. and Guieysse, B. (2015) Good Science for Improving Policy: Greenhouse Gas Emissions from Agricultural Manures. Animal Reproduction Science, 55, 691-701. https://doi.org/10.1071/AN13504

[42] Asai, H., Samson, B.K., Stephan, H.M., Songyikhangsuthor, K., Homma, K., Kiyono, Y., Inoue, Y., Shiraiwa, T. and Horie, T. (2009) Biochar Amendment Techniques for Upland Rice Production in Northern Laos. 1. Soil Physical Properties, Leaf SPAD and Grain Yield. Field Crops Research, 111, 81-84.

https://doi.org/10.1016/j.fcr.2008.10.008

[43] Gaskin, J.W., Speir, R.A., Harris, K., Das, K.C., Lee, R.D., Morris, L.A. and Fisher, D.S. (2010) Effect of Peanut Hull and Pine Chip Biochar on Soil Nutrients, Corn Nutrient Status, and Yield. Agronomy Journal, 102, 623-633. https://doi.org/10.2134/agronj2009.0083

[44] Cimo, G., Kucerik, J., Berns, A.E., Schaumann, G.E., Alonzo, G. and Conte, P. (2014) Effect of Heating Time and Temperature on the Chemical Characteristics of Biochar from Poultry Manure. Journal of Agricultural and Food Chemistry, 62, 1912-1918. https://doi.org/10.1021/jf405549z 
[45] Kloss, S., Zehetner, F., Dellantonio, A., Hamid, R., Ottner, F., Liedtke, V., Schwanninger, M., Gerzabek, M.H. and Soja, G. (2011) Characterization of Slow Pyrolysis Biochars: Effects of Feedstocks and Pyrolysis Temperature on Biochar Properties. Journal of Environmental Quality, 41, 990-1000. https://doi.org/10.2134/jeq2011.0070

[46] Novotny, E.H., de Freitas Maia, C.M.B., de Melo Carvalho, M.T. and Madari, B.E. (2015) Biochar: Pyrogenic Carbon for Agricultural Use-A Critical Review. Revista Brasileira de Ciência do Solo, 39, 321-344. https://doi.org/10.1590/01000683rbcs20140818

[47] Deng, W., van Zwieten, L., Lin, Z., Liu, X., Sarmah, A.K. and Wang, H. (2016) Sugarcane Bagasse Biochars Impact Respiration and Greenhouse Gas Emissions from a Latosol. Journal of Soils and Sediments, 17, 632-640.

https://doi.org/10.1007/s11368-015-1347-4

[48] Heitkötter, J. and Marschner, B. (2015) Interactive Effects of Biochar Ageing in Soils Related to Feedstock, Pyrolysis Temperature, and Historic Charcoal Production. Geoderma, 245-246, 56-64. https://doi.org/10.1016/j.geoderma.2015.01.012

[49] Ronsse, F., van Hecke, S., Dickinson, D. and Prins, W. (2013) Production and Characterization of Slow Pyrolysis Biochar: Influence of Feedstock Type and Pyrolysis Conditions. GCB Bioenergy, 5, 104-115. https://doi.org/10.1111/gcbb.12018

[50] Jeong, C.Y., Dodla, S.K. and Wang, J.J. (2016) Fundamental and Molecular Composition Characteristics of Biochars Produced from Sugarcane and Rice Crop Residues and by-Products. Chemosphere, 142, 4-13. https://doi.org/10.1016/j.chemosphere.2015.05.084

[51] Zavalloni, C., Alberti, G., Biasiol, S., Vedove, G.D., Fornasier, F., Liu, J. and Peressotti, A. (2011) Microbial Mineralization of Biochar and Wheat Straw Mixture in Soil: A Short-Term Study. Applied Soil Ecology, 50, 45-51. https://doi.org/10.1016/j.apsoil.2011.07.012

[52] Abruzzini, T.F. (2015) The Role of Biochar on Greenhouse Offsets, Improvement of Soil Attributes and Nutrient Use Efficiency in Tropical Soils. Ph.D. Thesis, University of São Paulo/ESALQ, São Paulo, X p.104.

\section{Submit or recommend next manuscript to SCIRP and we will provide best service for you:}

Accepting pre-submission inquiries through Email, Facebook, LinkedIn, Twitter, etc. A wide selection of journals (inclusive of 9 subjects, more than 200 journals)

Providing 24-hour high-quality service

User-friendly online submission system

Fair and swift peer-review system

Efficient typesetting and proofreading procedure

Display of the result of downloads and visits, as well as the number of cited articles

Maximum dissemination of your research work

Submit your manuscript at: http://papersubmission.scirp.org/

Or contact as@scirp.org 